\title{
EVOLUTION OF MUNICIPALITIES IN NEPAL: CHALLENGES AND PLANNING
}

\author{
Gopi Krishna Pandey*
}

\section{INTRODUCTION}

Urban center is an index of transformation from traditional rural economics to modern industrial unit. It is a long term process. It is progressive concentration of population in urban unit. Kingsley Davis has explained urbanization as a process of switch from spread out pattern of human settlements to one of concentration in urban centers. It is a finite process of cycle through which all nations pass as they evolve from agrarian to industrial society (Davis and Golden, 1954). In a more rigorous sense, urban center is such a place where exchange of services and ideas; a place for agro processing mills or small scale industries; a place for community and production services; a place for fair or hat (periodic market) or social gatherings; and place for transport service or break of bulk service. All these activities act as complement to each other, and are considered as a total strength of market force. Urban center is the foci of development activities for the rural development. Historical accounts show that some of the urban centers are in increasing trend and decreasing the number of commercial units. The urban centers which is located at the transportation node have chance to rapidly grow.

Nepal is undergoing a significant spatial transition. It is both the least urbanized country in South Asia with about 17 percent of its population living in urban areas (based on 2011census data, CBS, 2011) and the fastest unbanning country with an average population growth rate of about 6 percent per year since the 1976s. If Nepal urban population growth rate continuous at 3 percent per year as predicted' Nepal will become one third urban by 2045 (UNDE-SA, 2012). Nepal cities have the potential to drive the economic growth to benefit the entire country. Managing rapid urbanization is essential for improving growth, creating jobs and reducing poverty. The urban population of Nepal refers to the inhabitants residing in the recognized municipal areas. Nepalese municipal town is defined primarily in terms of population size. In 1952/54, settlements with a population of over 5,000 were generally recognized as towns although there was no formal definition. The 1961 census formally defined an urban area or a town (Sahar) as 'an areas with a population cluster of 5,000 and over, with an urban environment such as high-school, college, judicial and administrative offices, bazaar, communication facilities, mills, factories and so on. According to Nagar Panchayat Act of 1962 the settlements with minimum population of 10,000 and social services are Nagar Panchayat However, in 1976, the minimum population size of a Nagarpanchyat was fixed at 9,000. According to the municipality Act of 1991 and its amendment in 1997 any place in the Tarai with a minimum

Dr. Pandey is an Associate Professor, Geography Department, Padmakanya Multiple Campus, T.U., Bagbazar, Kathmandu, Nepal. 
population of 20,000 with infrastructure facilities, such as electricity roads, drinking water and communications, and in the hills and mountains with a population of 10,000 and infrastructure facilities, such as electricity, drinking water and communications can be declared an urban center. To define municipal town, it requires a status of an independent administrative unit and manages all its functions and development activities. Therefore, on the basis of the above definition urban centers consider all functional units located within its locality, which act as complement to each other and altogether act as the total strength of market force. The urban population of Nepal refers to the inhabitants residing in the designated Municipal area. The population census of Nepal defines urban localities or municipal town primarily in terms of population size. The Municipality Act 1992 and the Local self Government Act of 1999 redefined and classify Municipal towns. This is the first time that municipal areas have been classified into annual revenue and so on. But the minimum population size for the municipality remained to be 10,000 . At present the designated municipalities of Nepal are 58 in number. Since 2001 the number of municipal areas remained unchanged in 2011. Thus, in this country called Nepal the term" urban area" is used to denote areas officially defined as municipal areas. There is rapid growth of urban population in the city and municipalities due to natural growth as well as immigration in Nepal. The most urbanized region of the country is the Kathmandu valley where about 50 percent of total urban population of the country lives. Within this valley, Kathmandu the capital city of the country is one of the fastest growing cities in the country. Problem of municipalities is manifestation faulty urban planning, municipalities with poor economic base and without having functional categories. The spatial expansion of municipalities is taking place haphazardly resulting into grave environmental degradation. The holy rivers of municipalities have become drainage for sewer disposal. The solid waste disposal has also become the major problem in the municipalities. Policy should also relate to proper urban planning where city planning will consist of operational, developmental planning should care of improvement of urban infrastructure.

This paper attempts to analyze the evolution of municipalities in Nepal in terms of historical growth, growth of urban population, distribution of urban size classes and number of municipalities by population sizes by ecological region. Similarly, this paper also analyzed to show challenges, problems and planning situation of municipalities of Nepal. Since the database on market and urban centers is extremely limited the analysis will draw heavily on the market towns studies that have been conducted in the last few years by the Central Department of Geography, Tribhuvan University. On the other hand the census is the other source of comparable secondary data on urban centers in Nepal; it was used for the present study.

\section{HISTORICAL EVOLUTION OF MUNICIPALITIES IN NEPAL}

Nepal is a small country. It is one of the least urbanized countries in the world, with only about 14 percent of its population living in officially defined urban areas (CBS, 2001). The growth of urban centers is not a matter of chance. Their development, with a variety of functions like manufacturing, commerce, administration, cultural and social services, should be understood in relation to 
their regional resources in national context. All urban settlements derived their subsistence from tributary area. Multifarious activities are involved in the growth of towns. Manufacturing, commerce and trade, administrative, political functions, transport and communication, cultural and social services are some of the major activities involved in the process of urban growth.

The origin of first urban centers in Nepal took place in Kathmandu Valley. The historical evidences on the existence of towns in the Kathmandu Valley are found only in the Lichhavi period (100 B.C. to 1000 A.D.). It has been noted that during the Lichhavi period there were many settlements known as Grama in the Kathmandu Valley. The settlement at the present day site of Kathmandu City was known as Koligrama (Bajracharya, 1969 A.D.). As Gramas developed into commercial center they become known as Drangas (CEDA). The settlements in the southern part of the present Kathmandu known as Dakshin Koligrama developed into a prominent commercial center in the $10^{\text {th }}$ century A.D. Towards the end of the $10^{\text {th }}$ century A.D. further development and consolidation of Dranga evolved into an urban settlement known as Kantipur (Malla, 1969).

At the same time three major towns with urban characteristics had been developed in the Kathmandu Valley. Two factors seem to have contributed significantly to the growth of these towns of the valley. First, the fertile valley's high agricultural productivity could support a high density of people and some of people here engaged in commerce and production of goods (such as metal work and textile). Second, the strategic location of Kathmandu Valley as the trade link between Tibet and India further contributed to the development of these towns. Three major towns were strongly fortified. The elaborated network of walls and gateways defended them and secured their role as politico-economic centers (Shrestha and Malla, 1969).

During the medieval Malla period (1258-1768 A.D.), Nepal was divided into small principalities. The capitals of these principalities were loosely nucleus settlements amongst scattered peasant homesteads. A few among these later developed into larger settlements with urban characteristics. The most important impulses for urban growth during this period were the entrepot trade centered in the Kathmandu Valley. Some settlements along the trade route to Tibet also developed into market centers.

Throughout the nineteenth century (Rana period), towns in the hills developed slowly. They developed as centers for administration, trailer and craft production. Even indigenous petty commodity and craft production started to decline with the introduction of industrial goods from India by the early part of the twentieth century. As result hill towns ceased to be the centers of production and functioned merely as distribution centers.

With the construction of the east-west hill trail system and the need for administrative/political control, a small number of central places/trade centers grew along major trail routes leading to the Kathmandu Valley. The developments of central places were geared more towards military and political control than market interaction. Many urban centers developed are Dhulikhal, Dhankuta, Ilam (in eastern region), Jajarkot (in Midwestern region), Bandipur, 
Gorkha, and Tansen (in western region), Chainpur and Silgadhi (in Far Western region). They were located in hilltops rather than valleys from the point of view of military considerations for greater control and security. In the hilly region, some of the bigger urban settlements grew not in the hilltop but in the Valley like Katmandu and Pokhara.

The extension of the Indian railway network to the Nepalese border greatly enhanced the urban development process (Sharma, 1989). Many of the places where the Indian railway reached later developed as significant urban centers. With the improvement of trade relations with India in the $1920^{\mathrm{s}}$, a number of towns developed at the railheads or break-of- bulk points. These towns also facilitated the extension of the Indian market within Nepal. This development enhanced a pattern of north-south trade linkages which was seen in the growth of towns in the foot hills of the Tarai.

The Tarai also grew with the increased trade between Nepal and India after 1951 with increasing volume of imports from India. Some of these border towns such as Birgunj and Biratnagar grew rapidly as important centers of commerce supplying the manufactured goods to other parts of Nepal. This was further facilitated by the expansion of railway network of India along the Nepal India boarder, which made it convenient for movement of goods to Nepal. These boarder towns also become the location of a number of agro processing industries taking advantage of improved transportation facilities and larger agricultural resource base of the hinterland.

The rapid growth of Tarai towns therefore are a result of Nepal's increasing trading ties with India (after penetration of Nepalese markets by Indian manufactured goods), migration from the hills and transportation and industrial investments in Tarai. The growth of Tarai in recent year is also a spatial manifestation of Nepalese increasing economically dependent relationship with India and lack of development in the hills. In present time the growth of urban centers is very rapid because of the development of industrial revolution. Industrialization is always associated with commercial development. But, in Nepal industrial backwardness is a main constraint to the growth of large town and cities.

During the early $1960^{\mathrm{s}}$, the growing trend of the existing small markets picked up its momentum particularly in the Tarai with the destruction of the Tarai forest and eradication of malaria. The Tarai has become an attractive area for the hill people for migration. This has given a rise to a number of new small trading centers in the northern part of the Tarai close to the hill region. Similarly, the influx of Indian migrants provided impetus for the development of urban centers in the southern part of Tarai

The openings of new roads appear to be the first stage in the development of intensified marketing activities. Since the fifties, new roads have been constructed which made many areas accessible and the development of market town took place along them. The development of a large number of market centers along the roads bears witness to their strong influence upon the location of small trading centers. Such towns experienced a very considerable expansion of the government office and facilities. The expansion of commercial 
activities and their location emerged as a result of road provision. Therefore, different types and sizes of urban centers are developed along the Highways. However, roads alone cannot generate the network of dispersed trading centers. There must be demands for goods and services. When such demands become considerable the activities tend to get agglomerated in specific location giving rise to urban settlements. Therefore, the growth of population, increases of need of transport are equally important to account for growth of urban centers. Another important impetus for growth and decline of some hill towns in Nepal is the development of motorized transportation network linking major Hill and Tarai towns. These include:

(a) Araniko Highway linking Kathmandu to the Chinese boarder and to Tibet;

(b) Siddharatha Highway linking Hill towns of Pokhara with Butwal and Siddharathanagar in the Tarai;

(c) Prithivi Highway linking Pokhara with Kathmandu; and

(d) Mahendra Highway (east-west Highway) linking major urban centers of Tarai as well as north south road to Tarai;

(e) Tribhuvan Highway linking Kathmandu with Hetauda and Birganj in the central Tarai.

Similarly, the Banepa-Bardibas Highway linking Kavare Sidhuli and Mahotari in the Tarai region. With the development of Highway many urban centers have emerge.

With the improved transport facilities many of the market centers become nodes where travelers stop for food/ overnight accommodation or to catch/ change buses to other destinations. As a result, these market centers also developed as centers of tea shops, restaurants and hotels. The towns of Muglin, Dumre and waling have developed primarily because of these phenomena. Blaikie suggests that the rate of growth of small, new urban centers along the road is significantly greater than those off the road.

The establishment of Regional Development Centers (i.e. Eastern, Central, Western Mid western and far Western Development Regions) is an example of further development of some urban centers like Dhankuta in the Eastern Development Region, Birendranagar in the Midwestern Region, Pokhara in the Western Development Region. Similarly, Kathmandu is the capital city of Nepal in the Central Development Region and Dipayal in the Far Western Development Region. They were designated as regional development centers.

Trends towards the development of urban centers have not been uniform for the country as a whole. The pattern of development by mid 2005 showed that the eastern Tarai and Kathmandu Valley were highly prominent with a large number of urban centers followed by the central Tarai. The areas of the MidWestern and Far-Western Development Regions also show slowly increasing urban centers and municipality towns. In the mountain region urban development did not take place until the 1997. Two new urban places Bhimeswar in Dolakha district and Khandbari (Shankhuwasava district) were established in 1997. The 
difficulty of development of urban centers in the mountain region is due to barrier of terrain and low socio-economic condition of the people. The total number municipalities at present are 58 (Map 1.1).

Map 1.1

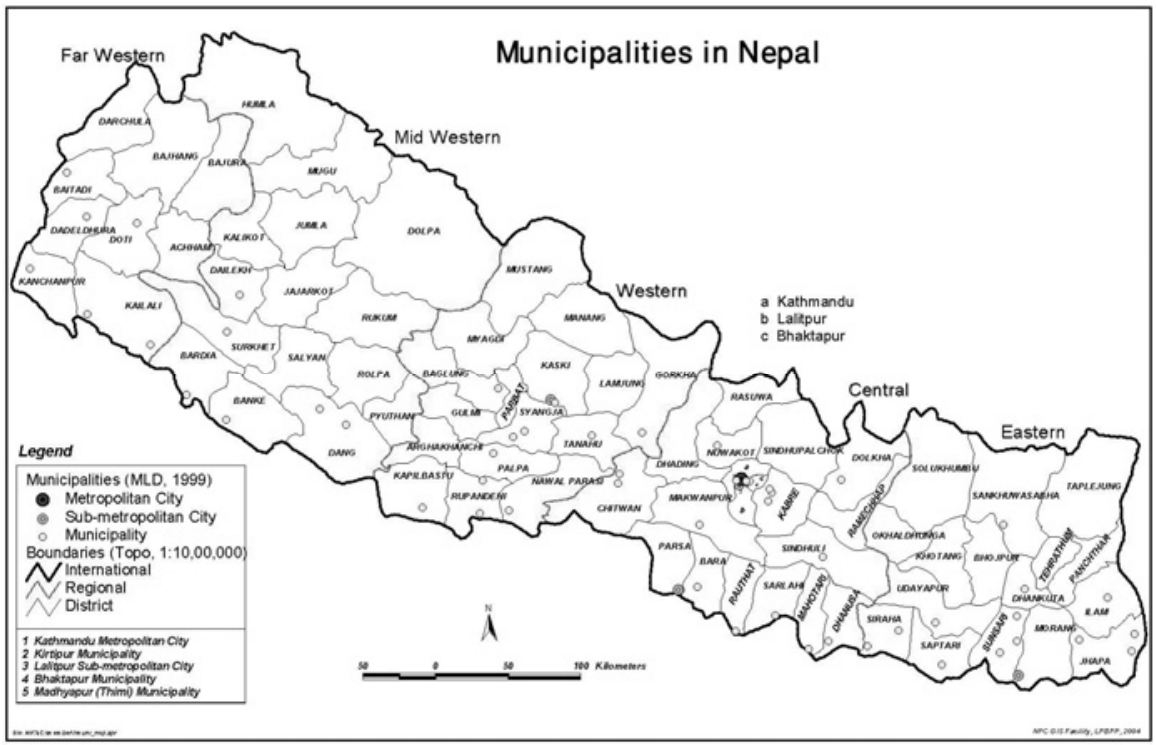

\section{DEVELOPMENT OF URBAN POPULATION IN NEPAL}

The first population census was taken in 1911. However, the first scientific census began in 1952/54 and therefore, this census year was considered as a base year for the definition of the urban localities. Since 1952 increase of municipalities and urban population have been increasing in Nepal (Table 1.1).

Table 1.1: The Development of Urban Population and Number of Municipalities in Nepal (1952-2011)

\begin{tabular}{|c|c|r|r|r|c|c|}
\hline \multirow{2}{*}{$\begin{array}{c}\text { Census } \\
\text { years }\end{array}$} & \multirow{2}{*}{$\begin{array}{c}\text { Number } \\
\text { Municipalities }\end{array}$} & \multirow{2}{*}{$\begin{array}{c}\text { Urban } \\
\text { population }\end{array}$} & \multirow{2}{*}{$\begin{array}{c}\text { Total } \\
\text { population }\end{array}$} & \multirow{2}{*}{$\begin{array}{c}\text { Percentage } \\
\text { of Urban } \\
\text { population }\end{array}$} & \multicolumn{2}{|c|}{$\begin{array}{c}\text { Annual growth rates } \\
\text { of population }\end{array}$} \\
\cline { 7 - 8 } & & & & Urban & \multicolumn{1}{c|}{ Total } \\
\hline 1952 & 10 & 238,275 & $8,256.625$ & 2.89 & - & - \\
\hline 1961 & 16 & 336,222 & $9,412,996$ & 3.57 & 4.6 & 1.56 \\
\hline 1971 & 16 & 461,938 & $11,555,983$ & 4.00 & 3.7 & 2.28 \\
\hline 1981 & 23 & 956,721 & $15,022,839$ & 6.37 & 10.7 & 3.00 \\
\hline 1991 & 33 & $1,695,719$ & $18,491,097$ & 9.17 & 7.7 & 2.31 \\
\hline 2001 & 58 & $3,227,879$ & $22,736,934$ & 14.20 & 9.0 & 2.30 \\
\hline 2011 & 58 & 4522382 & $26,494,504$ & 17.7 & - & 1.35 \\
\hline
\end{tabular}

In 1952, the population of Nepal was 8.3 million that increased to 26.4 million in 2011. During the same period, the population of municipal towns 
increased more than thirteen times. Likewise, the number of municipal towns increased from 10 in 1952 to 58 in 2011 . The proportion of urban population also went up from 2.89 percent in 1952 to 17.7 percent in 2011 .

The level of urbanization can be measured by the number and population size of Municipalities. The spatial distribution of Municipalities area in Nepal is markedly varied among three Ecological Regions.

Table 1.2: Number of Municipalities and Population Size by Ecological Regions (1952-2011)

\begin{tabular}{|l|c|c|c|c|c|c|c|}
\hline $\begin{array}{c}\text { Ecological } \\
\text { Regions }\end{array}$ & $\mathbf{1 9 5 2 / 5 4}$ & $\mathbf{1 9 6 1}$ & $\mathbf{1 9 7 1}$ & $\mathbf{1 9 8 1}$ & $\mathbf{9 1 9 1}$ & $\mathbf{2 0 0 1}$ & $\mathbf{2 0 1 1}$ \\
\hline Tarai & $\begin{array}{c}41,498 \\
(5)\end{array}$ & $\begin{array}{c}101,893 \\
(8)\end{array}$ & $\begin{array}{c}178,031 \\
(10)\end{array}$ & $\begin{array}{c}461,187 \\
(14)\end{array}$ & $\begin{array}{c}827,824 \\
(20)\end{array}$ & $\begin{array}{c}1,506,966 \\
(30)\end{array}$ & $\begin{array}{c}2,005,715 \\
(30)\end{array}$ \\
\hline Hill & $\begin{array}{c}196,777 \\
(5)\end{array}$ & $\begin{array}{c}234,329 \\
(8)\end{array}$ & $\begin{array}{c}283,907 \\
(6)\end{array}$ & $\begin{array}{c}495,534 \\
(9)\end{array}$ & $\begin{array}{c}867,895 \\
(13)\end{array}$ & $\begin{array}{c}1,677,208 \\
(26)\end{array}$ & $\begin{array}{c}2,468,110 \\
(26)\end{array}$ \\
\hline Mountain & - & - & - & - & - & 43,705 & $\begin{array}{c}49995 \\
(2)\end{array}$ \\
\hline Total & $\begin{array}{c}\mathbf{2 3 8 , 2 7 5} \\
\mathbf{( 1 0 )}\end{array}$ & $\begin{array}{c}\mathbf{3 3 6 , 2 2 2} \\
\mathbf{( 1 6 )}\end{array}$ & $\begin{array}{c}\mathbf{4 6 1 , 9 3 8} \\
\mathbf{( 1 6 )}\end{array}$ & $\begin{array}{c}\mathbf{9 5 6 , 7 2 1} \\
\mathbf{( 2 3 )}\end{array}$ & $\begin{array}{c}\mathbf{1 , 6 9 5 , 7 1 9} \\
\mathbf{( 3 3 )}\end{array}$ & $\begin{array}{c}\mathbf{3 , 2 2 7 , 8 7 9} \\
\mathbf{( 5 8})\end{array}$ & $\begin{array}{c}\mathbf{4 , 5 2 2 3 , 8 2 0} \\
(58)\end{array}$ \\
\hline
\end{tabular}

Note: Figure in parenthesis indicates the number of Municipalities. Source: CBS 1991, 2001 and 2012.

Table 1.2 indicates the distribution of urban areas and populations size of ecological regions of Nepal. In Nepal there are altogether 58 municipalities in 2011. The number of municipalities in the Tarai increased from 5 in 1952 to 30 in 2011 but the share in total urban population is 46.7 percent in Terai. The Hill Region have 26 municipalities and urban population is 52 percent. The remaining 1.3 percent is shared by the mountain region. The mountain region has only two municipalities.

Table 1.3 gives the distribution of urban size. The municipalities are also grouped into four classes on the basis of population size. This classification scheme is arbitrary. Class I includes urban places with a population over 100,000 which are termed as largest. The Class II and class III urban places have population of 60,000-100,000 and 40,000-60,000 respectively. They are referred to as 'large' and medium towns. The Class IV towns are small with less than 40,000 (Table 1.3).

Table 1.3: Distribution of Urban Size Classes, Nepal (2011)

\begin{tabular}{|c|l|c|c|c|c|}
\hline \multirow{2}{*}{ Class } & \multirow{2}{*}{ Population size } & \multicolumn{4}{|c|}{ Number of urban places } \\
\cline { 3 - 6 } & & Tarai & Hill & Mountain & Total \\
\hline I & Above 100,000 & 7 & 3 & - & 10 \\
\hline II & $60,000-100,000$ & 6 & 4 & - & 10 \\
\hline III & $40,000-60,000$ & 7 & 4 & - & 11 \\
\hline IV & Below 40,000 & 10 & 15 & 2 & 27 \\
\hline \multicolumn{2}{|c|}{ Total } & $\mathbf{3 0}$ & $\mathbf{2 6}$ & $\mathbf{2}$ & $\mathbf{5 8}$ \\
\hline
\end{tabular}

Source: CBS 1991, 2001 and 2012. 
By population size there are few number of municipalities with about 100,000 populations. Number of such municipalities is 5 . They are Biratnagar and Birjung in the Tarai and Kathmandu, Lalitapur and Pokhara in the hill. These are the largest municipalities in the country. Almost 8 numbers of municipalities belong to the second category with $60,000-100000$ population. Similarly, 10 municipalities belong to the third category with $40,000-60,000$ population (Table 1.3). Large numbers of municipalities have less than 40,000 populations. Number of such Municipalities is 35 (Figure 1.1).

Figure 1.1: Distribution of Urban Size Classes, Nepal (2011)

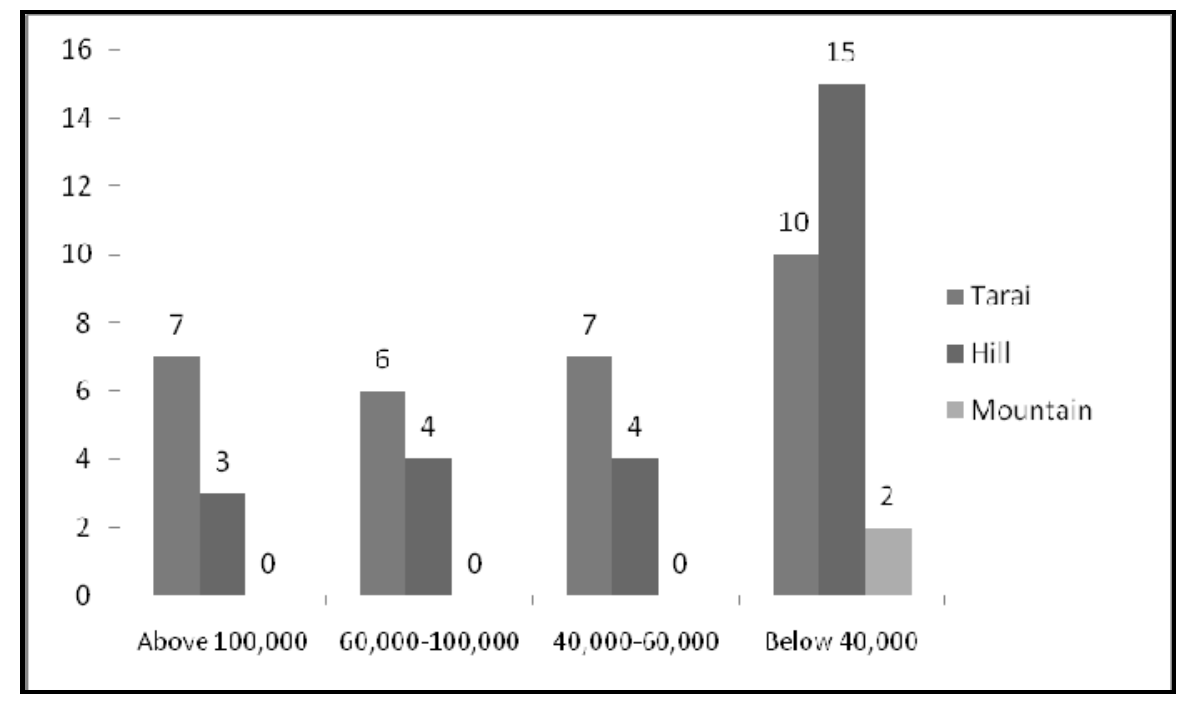

Source: CBS 1991, 2001 and 2012.

The municipality act '1992' changed the nomenclature of urban areas from Nagarpanchayet to 'Nagarpalika' or municipality. However, the status of local self-government unit of the municipality remained to be unchanged. In 1994, the incorporated towns' of Nepal have been classified into three levels such as metropolitan, sub-metropolitan and municipality based on population size, annual revenue and so on, but the minimum population size for the municipality remained to be 10,000 .

Urban areas are meeting minimum urban facilities such as electricity, drinking water, roads and communication etc. And Minimum population size for municipalities has been set as 20,000 for the Tarai and 10,000 for the Mountain and Hill regions. The annual revenue of Rs. 5 million is required for the urban areas in Tarai and minimum.0.5 million annual revenue for the mountain and Hill regions. Based on the different parameter, like population size and the annual revenue, municipalities urban area classified into three hierarchical levels such as:

(a) The area with more than 300,000 populations and with the annual revenue collection of over NRs. 400 millions is defined as Metropolitan city. 
(b) The area with more than 100,000 populations and with the annual revenue collection of over NRs. 100 million is defined as Submetropolitan city.

(c) A place of Tarai region having the minimum population of 20,000 and with the minimum annual revenue collections of 5 million is defined as municipalities. In the case of Hilly and Mountain region, the minimum population of 10,000 and with annual revenue collection of over NRs. 0.5 million is defined municipalities.

\section{CHALLENGES}

The rapid growth of urban areas or municipalities in Nepal, it becoming great challenges. The municipal authority that require urgent policy attention. One critical challenge is haphazard and uncontrolled growth of built up areas. Unplanned urban development in the Kathmandu valley has lead to rapid and uncontrolled sprawl, irregular substandard and inaccessible housing development; loss of open spaces and decrease livability. It has also increased vulnerability to disasters, making Kathmandu one of the most earth quake- vulnerable cities in the world.

Most urban areas of Nepal have cultural and heritage sites of varied nature including historical settlements monuments religious sites (temples, monasteries, and others) and ponds and public taps. These are of local, national and international significance some are listed as World heritage Sites by the United Nations Educational and scientific and cultural organization (UNESCO) (including the Pashupatinath Temple Boudhanath Swayambhunath Place areas of Hunumandokha, Patan and Bhakatapur, ChagunarayanTemple and Lumbini).

The informal and unplanned development comprises the natural beauty of historic settlement such as Lekhnath Pokhara and Tansen. Conversion of agricultural land and forest, as well as reclaiming of wetlands for urban uses and infrastructure, have resulted into the widespread removal of vegetation from the urban ecosystem and put additional pressure on nearby areas that may be even more ecologically sensitive. Loss in infiltration capacity of land due to increase in built up areas has lead to a higher frequency of flooding particularly in the lowest laying and poorest areas. However, according to IUCN (1999) "the physical states of the cultural and heritage sites and the monuments in Kathmandu Valley are fast deteriorating". The cultural and heritage sites along rivers are the worst affected. Furthermore, with the increasing of population in municipalities urban services like solid waste management is also becoming major problems as hapzard disposal of solid waste in densely populated areas, environmentally sensitive and river banks has made adverse impact on the environment and deteriorating the living standard and quality of life of the people. More than half of the municipalities have not even identified or proposed site for land filling their wastages. In general, waste is collected transported and disposed of by municiplites.Lack of resources; including human resources, infrastructure, and equipment; is a common problem faced by municipalities in attempting to 
manage solid waste. Siting and operation of landfills is highly sensitive and controversial. Many municipalities have worked in parternarship with the private sectors, on-governmental organizations (NGOS) and community groups in managing the solid waste. Kathmandu the only one metropolitan of the country does not have landfill site yet.

The numbers of motor vehicles in the larger urban centers has been increasing rapidly in recent years. This has not been matched by provision roads and infrastructure leading to persistent traffic congestion particularly in Kathmandu Valley towns. Urban development taking place, without adequate planning and provision of transport infrastructure and with inadequate consideration of the nature and composition of traffic. Urban roads are commonly narrow crooked and the road network function is poor. The availability of parking space is almost none or insufficient. The mixture of vehicles types, poor driving bad parking and road side trading added to traffic congestion. The consequences are prominent, longer travel time's greater level of air and noise pollution, with less efficient fuel consumption.

The situation of municipalities is also not very much different than that of natural status. One can easily observe the underdeveloped and mismanaged infrastructures like road, bridge, sewerage and drainage when passing through any of municipalities in Nepal. Traffic system are very weak, pollution is every where, increasing slums and squatters area, serve urban poverty are the increasing challenges that the urban managers are facing these days.

Emergence of urban slumps and squatter settlements in Nepal's' cities is relatively new and still small size compared with with other cities in South Asia. There were no adequate data on slum dwellers in Nepal nor is there is definition of "slums'. However, the number of slums and squatter settlements in major urban areas has been increasing in the last few years; it is most conspicuous in Kathmandu Valley. All the squatter localities and some of the core areas of Kathmandu are said to be slums due to lack of basic sanitation and utility facilities. The emergence and expansion of the squatter settlements has been encroaching upon riverbanks, public lands land belonging to temples or other religious cultural sites, agricultural lands and forest areas. The recent many urban studies has shown that gradually, slums and squatters settlements are emerging as the major challenges in most of the municipalities even outside the Kathmandu Valley. The emergence of other challenges and problems of municipalities such as the huge resources being invested in the housing and real estate sector in the country by different banking and financial institutions there is still lack of simple and affordable housing finance to cater the needs of the poor and low income families as they can not participate in the existing market of the housing finance due to high interest rate. Therefore, the biggest challenge in the country at present is how to make easy simple and affordable housing finance to the poor and low 
and low income families so that the poor and low income families could also get access to such finance to meet their housing needs.

\section{PLANNING}

Regional planning approach introduced in 1972 A.D.; has influenced both the national as well as local plan. Fifth five year National plan (1975-1980) can be regarded as the milestone in the field of urban planning because the plan had separate policy in this regard. The question arises; was regional planning approach not sufficient enough for the balance development in the country. The justification of such question comes from the fact that this approach failed to generate interregional exchange of various economic functions rather it provide some territorial framework for rural development and merely serve as administrative centre (Karki, 2004). The essential aim of urban planning is to promote the most effect spatial arrangement and social patterns of the component of the municipalities. The master of the city gives a broad general picture of the projected of the spatial patterns of the city. Urban planning aims at providing the facilities such as stores, factories, and residences most suitable location to each function in a city, an efficient transportation network connecting the length and breathe of a city and city beatification. By town planning proper care is taken of public places, parks and playgrounds. As regards houses, rules and regulations are made to see that lanes by lanes have been left and are adequate. Besides this rules ascertain that the houses will be airy, sunny and un spoilt by future expansions. The town planning authority supervises removal of slums and illegal constructions. It also makes arrangements to prevent recurrence of slums. The town planners are also responsible for providing fresh water and the disposal of used water and garbage. The Municipal Periodic Plan (MPP) preparation for the municipal bodies is a mandatory requirement under the Local-Self Government (LSGA) 1999 and regulations 1999 which provides a legal basis for execution of the manual development plans and programmes as well as for its eligibility for grant assistance by the central government substitute for octriotax in the past.

The LSGA 1999 has 'outlined a need of a participatory, comprehensive periodic plan of the municipalities comprised of sectoral goals outputs, activities and investment programmes project that are guided by or consistent with a long term strategic vision and physical development plan (20-25 years) of the municipality'. The pp is also envisaged to consist of short term actions plan and programmes (5-7 years) to resolve both city and community (ward) level problems. The town development act 1989 and amendments also provides for the formulation of the physical development plan for the growing urban areas and small town of the country. Similarly, National Urban policy 2007 has targeted three objectives; balance urban scenario, clean and prosperous urban environment and effective urban management. 


\section{URBAN POLICY}

In fact, cities should serve as the engine for rural development. UN Habitats slogan for World Habitat day 2004 is very relevant to our context as it rightly states: "Cities: engines of rural development. Therefore, urban policy should be formed in such a way as to boost two -way- traffic between rural and urban areas for further strengthening the existing linkages and socio-economic development in order to alleviate poverty and uplift the standard of living of people both in rural and urban areas. In this way, the development can be made more sustainable as this model will be based on the principle of mutual benefit and mutual development. Managing rapid urbanization poses challenges that require urgent policy attention one critical challenge is haphazard and un controlled growth of built up areas. Because they are classified as rural areas inspire of their urban characteristics, several market and border towns are growing 'under the radar' without government planning and control. Rapid population growth is over taking the capacities of existing institutions to manage urbanization of the valley. "The Kathmandu Valley Long term Development Plan" prepared by the Kathmandu Valley Town Development Committee in 2002, projected of population of 2.6 million in 2021.

\section{CONCLUSION}

There is rapid growth of urban population in the municipalities due to natural growth as well as immigration. Nepal is least urbanized but, fastest unbanning country in the South Asia with only 17 percent of its population living in officially defined urban areas (CBS, 2011). However, the rate of urban growth has been fast in recent decades. So with an urban population growth estimated at more than $5 \%$ every year on average since the 1970 , it is also one of the fastest unbanning countries of the region. Between 1952 and 2011, the number of formally designated urban centers grew from 10 to 58 , with a corresponding increase in urban population from 0.2 million to 6.2 million a sixteen fold increase. On the basis of above discussion an initial assessment, found the country has undergone major structural shifts over past few decades from an agricultural economy to a service based on. Kathmandu Valley is the most urbanized region in Nepal and its urban areas have been important economically administratively and politically for hundred of years. The regional distribution of urban centers is quite uneven. Of the 58 centers in 2011 only two are in the mountains. Of the remaining 56, 26 are in the hills and 30 in the Tarai. Among the newly designated urban centers, a large number are from the Tarai than from the hills. The role of administrative and political factors seems to have influenced the emergence and distribution of urban centers in the hill and mountain regions. Similarly, the expansion of the network of highways has impacted the growth of urban centers in the hill region. The emergence of urban centers in the Tarai began with the extension of the Indian railway network to the Nepalese border in the early decades of the twentieth century. Other reason is eradication of malaria generated a phenomenal migration 
from the hills to the Tarai. The spread of the road network has a great impact on growth and stagnation of particular locations. Population concentration and agglomeration of business activities are important causes of growth of urban centers. In present time municipalities, in Nepal particularly the Kathmandu valley facing serious challenges due to multiple factors like inadequate infrastructure, haphazard planning and poor business environment. Another problem has facing household access to piped water supply in urban Nepal has declined from $68 \%$ in 2003 to 58 percent in 2010. While Kathmandu Valley suffers from unplanned construction, infrastructure bottlenecks in coming years are feared to hit the city's productivity. We strongly advocated that the government prioritize investment in infrastructure connect cities internally and externally and make growth inclusive in order to foster growth and sustainability of municipality. Municipality's people are not getting enough service facilities to meet their demand. The situation of municipalities is also not very much different than that of natural status. One can easily observe the underdeveloped and mismanaged infrastructures like road, bridge, sewerage and drainage when passing through any of municipalities in Nepal. Traffic system are very weak, pollution is everywhere, increasing slums and squatters area, serve urban poverty are the increasing challenges that the urban managers are facing these days.

Similarly, managing rapid urbanization is essential for improving growth, creating jobs and reducing poverty. The plan and policies so far formulated to solve and control various forms of challenges should be strictly implemented.

\section{WORKS CITED}

Bajracharya, B.B. (1995). Promoting Small Towns for Rural Development: A View from Nepal." Asia- Pacific Population Journal. 10 (2) 27-49.

Bikie, P. Cameron, J., Seddon, D. (1976). of Roads in The effects West Central Nepal. Vols. 3, Overseas Development Administration, Norwich, England.

--- (1980). Nepal in Crisis, Growth and Stagnation at the Periphery. Oxford University Press, New Delhi.

Caplan, L. (1975). Administration and Politics in a Nepalese Town. Oxford, London.

CBS (Central Bureau of Statistics) (1958), Population Census 1952/54. Central Bureau of Statistics, Kathmandu.

CBS (Central Bureau of Statistics) (1968). Population Census 1971. (Vol. 5), Central Bureau Statistics, Kathmandu.

CBS (Central Bureau of Statistics) (1992). Population Census 1991. (Vol. 2) Central Bureau Statistics, Kathmandu.

CBS (Central Bureau of Statistics). (1998). Statistical Pocket Book. Central Bureau Statistics, Kathmandu.

CBS (2011). Preliminary Results of National Census 2068 (2011), Government of Nepal. 
74 EVOLUTION OF MUNICIPALITIES IN ...

CDG (Central Department of Geography) (1994-98). Identification of small Towns and Market Centers: Case Studies of different Districts of Nepal. Central Department of Geography, Kathmandu.

National Planning Commission (2068). Three Year Plan (2067-2070), NPC, Kathmandu.

National Urban Policy 2007. DUDBC/ MPVW, Nepal Government, Kathmandu.

Sharma, P. (1989), Urbanization in Nepal. No 110, Papers of the East-West Population Institute, East West Centre, Honolulu.

Shrestha, C.B. (1973/74), "The System of Central Places in Arniko Rajmarga Area. Himalayan Review. 5/6 19-39.

UN Habitat (2011). Cities and climate change. Global Report on Human Settlements 2011. United Nations Settlements Programme. London and Washington DC. 